\title{
PENGEMBANGAN MODUL BERBANTUAN GEOGEBRA PADA PERKULIAHAN GEOMETRI TRANSFORMASI
}

\author{
Ratri Isharyadi ${ }^{1}$, Marfi Ario ${ }^{2}$ \\ ${ }^{1}$ Program Studi Pendidikan Matematika, FKIP, Universitas Pasir Pengaraian \\ arya_math@ymail.com \\ ${ }^{2}$ Program Studi Pendidikan Matematika, FKIP, Universitas Pasir Pengaraian \\ marfi.ario.92@gmail.com
}

\begin{abstract}
ABSTRAK
Penelitian ini bertujuan untuk mengembangkan dan mengetahui kualitas bahan ajar berupa modul ajar berbantuan program geogebra pada perkuliahan geometri transformasi. Modul geometri transformasi berbantuan geogebra disusun dengan sistematis dan disertai dengan langkah-langkah penyelesaian masalah transformasi menggunakan geogebra. Jenis penelitian ini adalah penelitian pengembangan (Research and Development/ R\&D). Model pengembangannya yaitu 4D yang terdiri atas empat tahap, yaitu tahap pendefinisian, perancangan, pengembangan dan tahap pendiseminasian. Pada penelitian ini hanya dilakukan 3 tahap, yaitu tahap pendefinisian, tahap perancangan, dan tahap pengembangan. Instrumen penelitian yaitu berupa lembar validasi modul. Penilaian produk dilakukan oleh 3 orang validator yang terdiri dari 2 orang ahli materi dan 1 orang ahli media yang merupakan dosen program studi pendidikan matematika. Hasil penelitian menunjukkan bahwa penilaian dari kedua validator ahli materi terhadap modul geometri transformasi berbantuan geogebra yang dikembangkan memiliki rata-rata skor total 3,38 dengan kriteria sangat baik, sedangkan untuk validator ahli media memiliki rata-rata skor total 3,21 dengan kriteria sangat baik. Kriteria sangat baik hasil validasi ahli media dan ahli materi menunjukkan bahwa modul geometri transformasi berbantuan geogebra valid dan layak digunakan sebagai bahan ajar pada perkuliahan.
\end{abstract}

Kata Kunci : Modul, Geometri Transformasi, Geogebra

\begin{abstract}
This study aims to develop and find out the quality of teaching materials in the form of teaching modules assisted by the geogebra program on transformational geometry lectures. The Geogebra-assisted transformation geometry module is structured systematically and accompanied by steps to solve transformation problems using Geogebra. This type of research is development research (Research and Development / $R \& D$ ). The development model is $4 D$ which consists of four stages, namely defining, designing, developing and disseminating. In this study, only three steps were carried out, namely the defining, the design, and the development stage. The research instrument is a module validation sheet. The product assessment was carried out by 3 validators consisting of 2 material experts and 1 media expert who was a lecturer in the mathematics education study program. The results showed that the assessment of the two validators of material experts on the geogebra-assisted transformation geometry module developed had an average total score of 3.38 with very good criteria, while for validators media experts had an average total score of 3.21 with very good criteria. Very good criteria from the results of the validation of media experts and material experts showed that the geometry module of geogebraassisted transformation was valid and suitable for use as teaching material in lectures.
\end{abstract}

Keywords : Modul, Geometry Transformation, Geogebra 


\section{PENDAHULUAN}

Menurut NCTM (2000) geometri merupakan salah satu dari lima standar isi dalam matematika yaitu bilangan dan operasinya, aljabar, geometri, pengukuran, serta analisis data dan peluang. Lebih lanjut NCTM (2007) menyatakan bahwa geometri merupakan bagian matematika yang penting untuk dipelajari karena tiga alasan, yaitu: 1) bentuk-bentuk geometri banyak didasarkan pada benda didunia nyata seperti sarang lebah, balok kayu, dan dadu. 2) banyak permasalahan matematika yang dapat divisualisasikan dengan geometri, seperti statistika yang dapat digambarkan dalam berbagai diagram sehingga lebih mudah dipahami. 3) geometri merupakan sistem ilmu yang terstruktur yang terdiri dari aksioma, definisi, dan teorema sehingga memungkinkan ilmuwan melakukan pengembangan kemampuan berpikir logis dan sistematis melalui geometri.

Geometri mempelajari tentang titik, garis, bidang dan ruang serta sifat-sifat, ukuran-ukuran, dan keterkaitan satu dengan yang lain (Nur'aini, 2017). Geometri telah diajarkan sejak jenjang sekolah dasar hingga perguruan tinggi. Di Universitas Pasir Pengaraian, Geometri menjadi salah satu matakuliah wajib yang diajarkan kepada mahasiswa pendidikan matematika. Pembelajaran geometri dibagi kedalam tiga matakuliah yaitu Geometri, Geometri Analitik Bidang dan Ruang, serta Geometri Transformasi. Geometri transformasi memberikan dasar bagi transformasi geometri yang meliputi translasi, refleksi, rotasi, dilatasi, dan komposisi transformasi (Nu'man, 2015). Mata kuliah ini penting bagi mahasiswa calon guru matematika sebagai bekal untuk mengajarkan materi geometri di jenjang Sekolah. Hal ini mengingat bahwa geometri merupakan materi yang mendapat porsi terbesar $(41 \%)$ di jenjang SMP dibandingkan materi lain seperti aljabar (29\%), bilangan (18\%), serta statistika dan peluang (12\%) (Putra, 2011).

Groth (2013) menyatakan bahwa tujuan dasar mempelajari geometri yaitu memperoleh pemahaman, mampu mendefinisikan bentuk-bentuk geometri, dan mengkonstruksikan bukti. Sedangkan
Sasmita (2013) menyatakan bahwa tujuan pembelajaran geometri adalah untuk menumbuhkan kemampuan pemecahan masalah, berkomunikasi dan bernalar secara matematis. Selain itu tujuan pembelajaran geometri adalah untuk mengembangkan kemampuan berpikir logis, mengembangkan intuisi, menanamkan pengetahuan untuk menunjang materi lainnya dan dapat membaca serta menginterpretasikan argumen-argumen matematis.

Upaya untuk mencapai tujuan tersebut, mahasiswa difasilitasi dengan perkuliahan tatap muka dan buku teks yang relevan dengan mata kuliah geometri transformasi. Namun, fakta di lapangan ditemukan bahwa ketuntasan hasil belajar mahasiswa dalam perkuliahan geometri transformasi masih rendah. Mata kuliah ini dirasa sulit oleh sebagian besar mahasiswa. Berdasarkan pengalaman peneliti dalam mengampu mata kuliah geometri transformasi dan wawancara informal yang dilakukan pada mahasiswa Program Studi Pendidikan Matematika semester VI, rendahnya hasil belajar mahasiswa disebabkan oleh sumber belajar pada mata kuliah geometri transformasi ini masih sangat terbatas. Saat ini hanya terdapat versi potokopi buku ajar yang kondisinya juga sudah tidak terlalu jelas, karena buku tersebut merupakan cetakan lama dan tidak ada cetakan terbaru. Selain itu, content buku tersebut tidak memperhatikan keberagaman latar belakang kemampuan mahasiswa, dan bahasa yang digunakan juga terlalu tinggi, sehingga sulit dipahami oleh mahasiswa. Hal ini sesuai dengan pernyataan Aunurrahman (2010) bahwa selama proses belajar berlangsung, masalah belajar seringkali berkenaan dengan bahan belajar (materi) dan sumber belajar. Terbatasnya bahan ajar berkualitas diduga menjadi faktor utama penyebab kesulitan belajar geometri, khususnya bahan ajar yang berisi materi-materi pengayaan (Pangesti, 2017).

Mencermati hal tersebut, maka perlu dikembangkan bahan ajar yang mampu membantu mahasiswa dalam belajar dan memahami materi. Keberadaan bahan ajar menjadi penting karena dosen dan 
mahasiswa cenderung bergantung kepada bahan ajar yang dimiliki (Owon, 2017). Salah satu manfaat penggunaan bahan ajar adalah dapat meningkatkan efektivitas pembelajaran serta memperbaiki kualitas pembelajaran (Gazali, 2016).

Menurut Depdiknas (2007) bahan ajar merupakan seperangkat materi yang disusun secara sistematis baik tertulis maupun tidak sehingga tercipta lingkungan/suasana yang memungkinkan siswa untuk belajar. Beberapa karakteristik dari bahan ajar menurut Bruri, dkk (2009) adalah sebagai berikut: 1) self instructional, yaitu bahan ajar dapat membuat siswa mampu membelajarkan diri sendiri dengan bahan ajar yang dikembangkan; 2) Self contained yaitu seluruh materi pelajaran dari satu unit kompetensi atau subkompetensi yang dipelajari terdapat di dalam satu bahan ajar secara utuh; 3) Stand alone (berdiri sendiri) yaitu bahan ajar yang dikembangkan tidak tergantung pada bahan ajar lain atau tidak harus digunakan bersama-sama dengan bahan ajar lain; 4) Adaptive yaitu bahan ajar hendaknya memiliki daya adaptif yang tinggi terhadap perkembangan ilmu dan teknologi; 5) User friendly yaitu setiap intruksi dan paparan informasi yang tampil bersifat membantu dan bersahabat dengan pemakainya, termasuk kemudahan pemakai dalam merespon dan mengakses sesuai dengan keinginan.

Selain keterbatasan sumber belajar, permasalahan lain yang ditemukan yaitu sebagian besar mahasiswa menyatakan kesulitan dalam memvisualisasikan bentuk geometri. Hal ini dikarenakan geometri memiliki keabstrakan objek, sehingga menuntut mahasiswa untuk mampu membayangkan hal-hal yang tidak jelas bentuk fisiknya (Paradesa, 2016). Pernyataan tersebut didukung juga oleh hasil penelitian Praveen \& Leong (2013) yang mengungkapkan bahwa kesulitan yang dialami dalam memahami geometri adalah karena kesulitan dalam memvisualisasikannya. Akibatnya mereka tidak dapat memahami secara utuh suatu materi geometri.
Melihat realitas tersebut, maka bahan ajar yang dikembangkan harus mampu membantu mahasiswa dalam memvisualisasikan bentuk geometri. Pemanfaatan geogebra dapat menjadi salah satu solusi terbaik. Hal ini karena geogebra mampu mendemonstrasikan atau memvisualisasikan konsep-konsep matematis (Mahmudi, 2011). Lebih lanjut dijelaskan bahwa pemanfaatan program geogebra memberikan beberapa kelebihan diantaranya: mampu memberikan lukisanlukisan geometri dengan cepat dan teliti; dapat memberikan pengalaman visual yang lebih jelas dalam memahami konsep geometri; mempermudah menyelidiki atau menunjukkan sifat-sifat yang berlaku pada suatu objek geometri (Mahmudi dalam Nursyahidah, 2016). Menurut Nur (2016) geogebra dapat dimanfaatkan sebagai media demonstrasi dan visualisasi; alat bantu konstruksi, alat bantu penemuan konsep matematika; dan untuk menyiapkan bahan-bahan pengajaran.

Berdasarkan beberapa penelitian sebelumnya, seperti penelitian Zulnaidi \& Zakaria (2012) menunjukkan bahwa geogebra dapat meningkatkan kemampuan pemahaman konsep siswa pada materi fungsi, hal ini dikuatkan oleh hasil penelitian yang dilakukan oleh Bakar, Ayub, Tarmizi, \& Luan (2015) yang juga menunjukkan geogebra secara positif dapat meningkatkan kemampuan matematika siswa pada topik fungsi kuadrat. Dengan demikian bahan ajar geometri transformasi berbantuan program geogebra diharapkan mampu menjadi alternatif bagi mahasiswa khususnya mahasiswa pendidikan matematika Universitas Pasir Pengaraian dalam mengatasi permasalahanpermasalahannya selama ini dalam mempelajari geometri transformasi. Berdasarkan uraian di atas, maka tujuan penelitian ini adalah mengembangkan bahan ajar geometri transformasi berbantuan program Geogebra yang valid bagi mahasiswa pendidikan matematika Universitas Pasir Pengaraian. 


\section{METODE PENELITIAN}

Penelitian ini merupakan penelitian R\&D (Research and Development). Produk yang ingin dikembangkan yaitu bahan ajar geometri transformasi berbantuan program Geogebra. Model pengembangan yang digunakan adalah model pengembangan 4D yang merupakan singkatan dari define, design, development, and dissemination. Pada penelitian ini hanya dilakukan sampai tahap ketiga.

Tahap pendefinisian (define) dilakukan guna melihat gambaran kondisi di lapangan yang berkaitan dengan proses belajar mengajar geometri transformasi di program studi pendidikan matematika Universitas Pasir Pengaraian, kemudian menganalisis permasalahan. Tahap perancangan (design) merupakan kegiatan merancang modul geometri transformasi berbantuan geogebra. Modul berisi kata pengantar, daftar isi, uraian materi, langkah-langkah penggunaan geogebra dalam penyelesaian masalah, contoh soal, latihan, dan daftar pustaka. Penyajian modul terdiri atas tiga materi, yaitu refleksi, setengah putaran, translasi yang disesuaikan dengan silabus pembelajaran. Tahap pengembangan merupakan kegiatan untuk menilai validitas, praktikalitas, dan efektivitas bahan ajar yang dikembangkan. Validasi dilakukan oleh tiga validator, yang terdiri atas validator ahli materi yaitu dua orang dan validator ahli media satu orang. Pada artikel ini hanya akan dibahas tentang validitas.

Penelitian ini dilaksanakan di Universitas Pasir Pengaraian dengan subjek penelitian yaitu mahasiswa program studi pendidikan matematika semester VI yang berjumlah 26 orang. Data pada penelitian ini merupakan data validitas yang diperoleh melalui angket. Data dari hasil lembar validasi bahan ajar dan tes mata kuliah geometri transformasi dianalisis secara kuantitatif, kemudian digunakan teknik deskriptif untuk menarik kesimpulan yang bersifat kualitatif.

Teknik Pengumpulan Data dan Analisis Data

Dalam proses validasi, tim ahli diberi lembar observasi yang berisi beberapa pernyataan dengan skala likert. Skor yang diperoleh dengan menggunakan skala likert ini kemudian diberi rerata. Masing-masing jawaban yang diperoleh diberi skor dengan kriteria sebagai berikut (Ali, 2009):

$\begin{array}{ll}\text { Skor } & \text { Kriteria } \\ 4 & \text { sangat baik } \\ 3 & \text { baik } \\ 2 & \text { cukup } \\ 1 & \text { kurang } \\ 0 & \text { sangat kurang }\end{array}$

Analisis perhitungannya adalah:

Nilai $=\frac{\text { jumlah skor validasi keseluruhan responden }}{\text { banyak pertanyaan } \mathrm{x} \text { banyak responden }}$

Interpretasi nilai yang diperoleh ditentukan dengan aturan berikut. Untuk skor maksimum 4 dan minimum 0 , maka rentang skor $(\mathrm{R})$ adalah $4-0=4$. Karena penilaian akan dibagi dalam 5 kelas, maka panjang kelas intervalnya adalah 4:5 $=0,8$. Secara kontinu penilaian validitas dapat diinterpretasikan dengan kategori berikut:

Tabel 1. Interpretasi Data Validitas Modul Geometri Transformasi

\begin{tabular}{cc}
\hline Interval & Kriteria \\
\hline $0,00 \leq$ Nilai $\leq 0,80$ & Sangat Kurang \\
$0,80<$ Nilai $\leq 1,60$ & Kurang \\
$1,60<$ Nilai $\leq 2,40$ & Cukup \\
$2,40<$ Nilai $\leq 3,20$ & Baik \\
$3,20<$ Nilai $\leq 4,00$ & Sangat Baik \\
\hline
\end{tabular}

Modul pembelajaran geometri transformasi berbantuan geogebra dikatakan valid jika masuk pada kategori baik atau sangat baik. Proses validasi juga dilakukan dengan diskusi dan wawancara. Teknik deskriptif digunakan untuk menggambarkan data hasil wawancara. Miles dan Huberman dalam Nyimas (2007: 62) menyatakan "bahwa 
hasil wawancara dari para pakar menghasilkan data kualitatif berdasarkan transkripsi tertulis dan catatan yang dibuat saat wawancara berlangsung".

\section{HASIL DAN PEMBAHASAN}

Pada tahap pendefinisian (define), dilakukan beberapa kegiatan, yaitu:

1. Menganalisis Kurikulum

Tujuan dilakukannya analisis kurikulum yaitu untuk menetapkan kompetensi bahan ajar yang akan dikembangkan. Pada tahap ini peneliti menganalisis Rencana Pembelajaran Semester (RPS) mata kuliah geometri transformasi yang digunakan.

2. Menganalisis dan Mereview Buku Rujukan

Pada tahap ini peneliti mengumpulkan buku-buku perkuliahan geometri transformasi yang relevan dengan pokok bahasan yang dikembangkan dan artikelartikel pengembangan pembelajaran menggunakan program geogebra.

3. Mempelajari Karakteristik Mahasiswa

Mahasiswa pendidikan matematika

Universitas Pasir Pengaraian berasal dari berbagai daerah di Kabupaten Rokan hulu, yang berasal dari berbagai tingkat kemampuan matematis. Kesulitan-kesulitan yang dialami mahasiswa umumnya pada saat memvisualisasikan bentuk geometri, serta visualisasi dari transformasinya. Berdasarkan wawancara terbuka dengan mahasiswa, menunjukkan bahwa bahan ajar yang mereka gunakan sebelumnya menggunakan bahasa yang tinggi, sehingga mahasiswa kesulitan dalam memahaminya.

4. Melakukan Diskusi dengan Teman Sejawat
Diskusi dilakukan guna melihat kebutuhan bahan ajar bagi mahasiswa dari sudut pandang Dosen. Hasil diskusi menunjukkan bahwa usaha mahasiswa dalam mencari sumber belajar masih kurang, mereka cenderung memanfaatkan bahan ajar yang ada. Perlu suatu bahan ajar yang dapat memfasilitasi mahasiswa dan memudahkan mahasiswa dalam mempelajari geometri transformasi.

Selanjutnya yaitu tahap perancangan (design) yaitu kegiatan merancang modul geometri transformasi berbantuan geogebra. Modul berisi cover, kata pengantar, daftar isi, uraian materi, langkah-langkah penggunaan geogebra dalam penyelesaian masalah, contoh soal, latihan, dan daftar pustaka. Penyajian modul terdiri atas tiga materi, yaitu refleksi, setengah putaran, translasi yang disesuaikan dengan silabus pembelajaran.

Setelah tahap perancangan selesai, selanjutnya yaitu tahap validasi dengan ahli media dan ahli materi untuk mengetahui apakah modul yang dikembangkan valid atau tidak. Validator ahli materi yaitu Riska Novia Sari, M.Pd dari Universitas Riau Kepulauan dan Hera Deswita, M.Pd dari Universitas Pasir Pengaraian. Sedangkan validator ahli media yaitu Dr. Nofriyandi, M.Pd dari Universitas Islam Riau. Lembar validasi untuk ahli materi terdiri dari 27 pernyataan dengan rincian 10 pernyataan untuk kelayakan isi, 8 pernyataan untuk kelayakan penyajian dan 9 pernyataan kelayakan kebahasaan. Berikut hasil perhitungan kevalidan modul berdasarkan penilaian kedua validator ahli materi.

Tabel 2. Hasil Validasi Kelayakan Modul oleh Ahli Materi

\begin{tabular}{llcccc}
\hline \multirow{2}{*}{ No } & \multirow{2}{*}{ Aspek yang dinilai } & \multicolumn{2}{c}{$\begin{array}{c}\text { Rata-rata skor } \\
\text { dari validator }\end{array}$} & \multirow{2}{*}{$\begin{array}{c}\text { Rata-rata } \\
\text { skor }\end{array}$} & \multirow{2}{*}{ Kriteria } \\
\cline { 3 - 4 } & & 1 & 2 & & \\
\hline 1 & Kelayakan isi & 3,40 & 3,40 & 3,40 & Sangat baik \\
2 & Kelayakan penyajian & 3,25 & 3,37 & 3,31 & Sangat baik \\
3 & Kelayakan kebahasaan & 3,44 & 3,44 & 3,44 & Sangat baik \\
\hline \multicolumn{2}{c}{ Rata-rata skor total } & & & 3,38 & Sangat baik \\
\hline
\end{tabular}


Selanjutnya hasil validator ahli media kegrafikan sebagai berikut. dengan aspek penilaian kelayakan

Tabel 3. Hasil Validasi Kelayakan Modul oleh Ahli Media

\begin{tabular}{cccc}
\hline \multirow{2}{*}{ Aspek yang dinilai } & Indikator & $\begin{array}{r}\text { Rata-rata } \\
\text { skor }\end{array}$ & \multirow{2}{*}{ Kriteria } \\
\hline Kelayakan kegrafikan & Ukuran modul & 3,50 & Sangat baik \\
\cline { 2 - 4 } & Disain sampul modul (cover) & 3,14 & Baik \\
\cline { 2 - 4 } & Disain ini modul & 3,00 & Baik \\
\hline \multicolumn{2}{c}{ Rata-rata skor total } & 3,21 & Sangat baik \\
\hline
\end{tabular}

Berdasarkan hasil validasi pada tabel 2 dan 3 di atas, diperoleh skor rata-rata total adalah 3,38 dan 3,21 yang termasuk kriteria sangat baik. Menurut kriteria kevalidan yang telah ditetapkan, maka modul geometri transformasi berbantuan geogebra yang telah dikembangkan dapat dikatakan valid dan layak untuk digunakan dalam perkuliahan geometri transformasi.

Adapun kesimpulan dari ketiga validator menunjukkan modul layak digunakan dengan revisi. Berikut beberapa masukan dari ketiga validator yaitu, (a) beberapa ruang kosong pada modul agar di efektifkan penggunaannya, (b) tambahkan latihan-latihan soal, (c) ilustrasi pada modul disesuaikan dengan kehidupan sehari-hari, (d) penggunaan simbol-simbol matematika yang tidak sesuai agar diperbaiki. Selanjutnya dilakukan perbaikan sesuai dengan masukan dan saran dari validator.

\section{KESIMPULAN}

Berdasarkan hasil penelitian dan pembahasan dapat disimpulkan bahwa, (1) pengembangan modul geometri transformasi berbantuan geogebra dilakukan melalui 3 tahap dari 4 tahap model 4-D yaitu tahap yaitu tahap pendefinisian, tahap perancangan, dan tahap pengembangan. Hasil pengembangan berupa modul geometri transformasi berbantuan geogebra yang terdiri atas tiga materi, yaitu refleksi, setengah putaran, translasi yang disesuaikan dengan silabus pembelajaran, dan (2) hasil pengujian kevalidan modul dari ketiga validator dengan rincian rata-rata skor total ahli materi dan ahli media masing-masingnya yaitu 3,38 dan 3,21 dengan kriteria keduanya yaitu sangat baik. Dengan demikian modul yang dikembangkan merupakan modul yang valid dan layak digunakan.

\section{UCAPAN TERIMAKASIH}

Ucapan terimakasih untuk DRPM Dikti atas bantuan dana pada penelitian ini dalam skema penelitian dosen pemula dan kepada pihak-pihak terkait yang telah membantu telaksananya penelitian ini.

\section{DAFTAR PUSTAKA}

Ali M. (2009). Pengembangan media pembelajaran interaktif mata kuliah medan elektromagnetik. Jurnal Edukasi @Elektro. 5(1): 11-18.

Aunurrahman. (2010). Belajar dan Pembelajaran. Bandung: Alfabeta.

Bakar, K. A., Ayub, A. F. M., Tarmizi, R. A., \& Luan, W. S. (2015). Effect of teaching mathematics using GeoGebra on students' with dissimilar spatial visualisation. AIP Conference Proceedings, 1682

Bruri Triyono, dkk. (2009). Pengembangan bahan ajar. Materi diklat training of trainer calon tenaga pengajar/dosen lingkungan badiklat perhubungan tahun 2009. Kerjasama badan diklat departemen perhubungan dengan magiseter sistem dan teknik transportasi universitas gadjah mada dan akademi militer (Akmil) Magelang. 
Depdiknas. (2007). Materi Sosialisasi dan Pelatihan Kurikulum Tingkat Satuan Pendidikan (KTSP). Jakarta: Depdiknas.

Gazali, R.Y. (2016). Pengembangan bahan ajar matematika untuk siswa SMP berdasarkan teori belajar Ausubel. Pythagoras: Jurnal Pendidikan Matematika. 11(2): 182-192.

Groth. R.E. (2013). Teaching Mathematics in grade 6-12. Los Angeles, CA: SAGE Publications.

Mahmudi, A. (2011). Pemanfaatan Geogebra dalam Pembelajaran Matematika. Makalah pada Seminar Nasional LPM UNY.

NCTM. (2000). Principles and Standards for School Mathematics. Reston, VA:

NCTM. (2007). From 1990s: What should not be in the algebra and geometry curricula of average college-bound students?. Mathematic Teacher. 100, 72-74.

Nu'man, M. (2015). Pengembangan bahan ajar geometri transformasi berdasarkan problem based learning untuk memfasilitasi kemampuan komunikasi matematis mahasiswa pendidikan matematika UIN Sunan Kalijaga. Prosiding Seminar Nasional Matematika dan Pendidikan Matematika UMS. Hal. 345-354.

Nur'aini, I.L., dkk. (2017). Pembelajaran matematika geometri secara realistis dengan geogebra. Jurnal Matematika. 16 (2): 1-6.

Nur, I.M. (2016). Pemanfaatan program geogebra dalam pembelajaran matematika. Jurnal Matematika dan Pendidikan Matematika. 5 (1): 10-19

Nursyahidah, F., Saputro, B. A., \& Prayitno, M. (2016). Kemampuan
Penalaran Matematis Siswa SMP dalam Belajar Garis dan Sudut dengan GeoGebra. Suska Journal of Mathematics Education, 2(1), 13-19.

Nyimas Yasmin. (2007). "Pengembangan Perangkat Pembelajaran Matematika Berbasis RME (Realitstic Mahematics Education) Dilaksanakan Secara Terbatas di SD Negeri 24 Padang". Tesis tidak diterbitkan. Padang: Pascasarjana UNP.

Owon, R.A.S. (2017). Pengembangan bahan ajar menulis berbagai jenis teks bertema kearifan lokal Sikka bagi siswa SMP. Jurnal Inovasi Pembelajaran. 3(1): 528-541.

Pangesti, F.T.P. dan Retnowati, E. (2017). Pengembangan bahan ajar geometri SMP berbasis cognitive load theory berorientasi pada prestasi belajar siswa. Pythagoras: Jurnal Pendidikan Matematika. 12 (1) : 3346.

Paradesa, R. (2016). Pengembangan bahan ajar geometri transformasi berbasis visual. Jurnal Pendidikan Matematika JPM RAFA. 2 (1) : 56-84

Praveen, S., \& Leong, K. E. (2013). Effectiveness of Using Geogebra on Students' Understanding in Learning Circles. The Malaysian Online Journal of Educational Technology, 1(4), 1-11.

Putra, H.D. (2011). Pembelajaran geometri dengan pendekatan SAVI berbantuan wingeom untuk meningkatkan kemampuan analogi matematika siswa SMP. Prosiding Seminar Nasional Pendidikan Matematika STKIP Siliwangi Bandung. Vol. 1 hal. 1-11.

Sasmita, I. G. A. L., Wirya, I. N., \& Margunayasa, I. G. (2013). Pengaruh Teori Van Hiele Dalam Pembelajaran 
Ratri Isharyadi, Marfi Ario

Geometri Terhadap Hasil Belajar Siswa Kelas V SD di Desa Sinabun. MIMBAR PGSD Undiksha, 1(1).

Zulnaidi, H., \& Zakaria, E. (2012). The

conceptual and procedural knowledge of high school mathematics students. Asian Social Science, $8(11)$, 102 effect of using GeoGebra on 